\title{
COVİD-19 Sürecinde Peyzaj Mimarlığı Öğrencilerinin Acil Uzaktan Öğretim Sistemi Üzerine Görüşleri: Burdur Mehmet Akif Ersoy Üniversitesi Örneği
}

\author{
Bora Bingö $1^{1 *}$ \\ ${ }^{1 *}$ Burdur Mehmet Akif Ersoy Üniversitesi, Mühendislik Mimarlık Fakültesi, Peyzaj Mimarlığı Bölümü, Burdur, Türkiye (ORCID: 0000-0001-9644-0921) \\ bbingol@mehmetakif.edu.tr
}

(İlk Geliş Tarihi 5 Ekim 2020 ve Kabul Tarihi 24 Aralık 2020)

(DOI: $10.31590 /$ ejosat.805398)

ATIF/REFERENCE: Bingöl, B. (2020). COVID-19 Sürecinde Peyzaj Mimarlı̆̆ı Öğrencilerinin Acil Uzaktan Öğretim Sistemi Üzerine Görüşleri: Burdur Mehmet Akif Ersoy Üniversitesi Örneği. Avrupa Bilim ve Teknoloji Dergisi, (20), 890-897

$\ddot{O} \mathbf{z}$

2019 yılının sonlarında ortaya çıkan ve tüm dünyayı kısa sürede etkisi altına alan COVID-19 pandemisi günümüzde de hâlen tüm ülkeler için ciddi bir tehdit oluşturmaktadır. Bu tehdit ile birlikte gerek günlük yaşam, gerekse ülke sistemleri de olumsuz etkilenmiş ve değişim geçirmiş̧tir. Bu sistemlerin en önemlilerinden bir tanesi olan eğitim sistemi de bu süreçte büyük sıkıntılar yaşamakta ve bunları aşmakta zorlanmaktadır. Bu dönemde, Türkiye'de de eğitimin aksamaması için tüm eğitim ve öğretim süreçlerinin uzaktan öğretim sistemi ile yürütülmesine karar verilmiştir. Bu çalışma, COVID-19 pandemi döneminde, Burdur Mehmet Akif Ersoy Üniversitesi Peyzaj Mimarlığı Bölümü lisans öğrencilerinin, acil uzaktan öğretim sistemine ilişkin memnuniyetlerinin ölçülmesi ve sistemin değerlendirilerek, peyzaj mimarlığ1 bölümlerinde uygulanabilirliğini ölçmek amacıyla gerçekleştirilmiştir. Çalışmada COVID-19 pandemi süreci değerlendirilerek, eğitim ve öğretim sistemi üzerine etkileri incelenmiş, acil uzaktan öğretim sistemine dair öğrenci görüşlerini elde edebilmek için de anket çalışması yapılmıştır. Sisteminin daha iyi uygulanabilmesi ve eğitimde yaşanabilecek sorunların en aza indirilmesini sağlamak amacıyla çalışmada elde edilen veriler değerlendirilerek, öneriler sunulmuştur.

Anahtar Kelimeler: COVİD-19, Acil uzaktan öğretim, Öğretim süreci, Peyzaj mimarlı̆̆ı, Burdur

\section{Landscape Architecture Students' Views on Emergency Remote Teaching System in the COVID-19 Process: The Case of Burdur Mehmet Akif Ersoy University, Turkey}

\begin{abstract}
The COVID-19 pandemic, which emerged at the end of 2019 and affected the whole world in a short time, still poses a serious threat to all countries today. With this threat, both daily life and country systems were negatively affected and changed. The education system, which is one of the most important of these systems, has great difficulties in this process and has difficulty overcoming them. During this period, it agreed to conduct emergency remote teaching system for all education and training process in Turkey as well to avoid disruption of training. This study was carried out during the COVID-19 pandemic period in order to measure the satisfaction of undergraduate students studying at the Department of Landscape Architecture at Burdur Mehmet Akif Ersoy University regarding the emergency remote teaching system and to evaluate the applicability of the system in landscape architecture departments. In the study, the COVID-19 pandemic process was evaluated, its effects on the education and training system were examined, and a survey was conducted to obtain student views on the emergency remote teaching system. Suggestions were made by evaluating the data obtained in the study in order to implement the system better and to minimize the problems that may occur in education.
\end{abstract}

Keywords: COVID-19, Emergency remote teaching, Teaching process, Landscape architecture, Burdur

\footnotetext{
* Sorumlu Yazar: Burdur Mehmet Akif Ersoy Üniversitesi, Mühendislik Mimarlık Fakültesi, Peyzaj Mimarlığı Bölümü, Burdur, Türkiye, ORCID: 0000-0001-9644-0921, bbingol@mehmetakif.edu.tr
} 


\section{Giriş}

1 Aralık 2019 tarihinde, Çin'in Hubei bölgesinin başkenti olan Wuhan'da ortaya çıktığı iddia edilen ve hızla tüm dünyada yayılmaya başlayan COVİD-19 pandemisi, günümüzde tüm ülkeleri tehdit eder bir hâl almıştır. Dünya genelinde tüm ülkelerde artan ölüm ve vaka sayıları, alışkanlıklarımızın ve yaşayış biçimlerimizin de değişmesine neden olmuştur. Salgın, dünya çapında halk sağlığı hakkında büyük endişelere neden olmaktadır (Taş ve Yağanoğlu, 2020). Türkiye'de ise ilk COVID-19 vakası, 11 Mart 2020 tarihinde görülmüştür (Anonim, 2020a). Aynı tarihte de Dünya Sağlık Örgütü, bu yeni gelişen virüsün bir pandemi olduğunu açıklamıştır (Anonymous, 2020a). Yaşanan süreç içerisinde 17.09.2020 tarihine kadar COVID-19 pandemisi, dünyada 29.679.284 doğrulanmış vaka ve 936.521 ölüm sayısına, ülkemizde ise 294.620 doğrulanmış vaka ve 7.186 ölüm sayısına ulaşmıştır (Anonymous, 2020b) (Şekil 1).

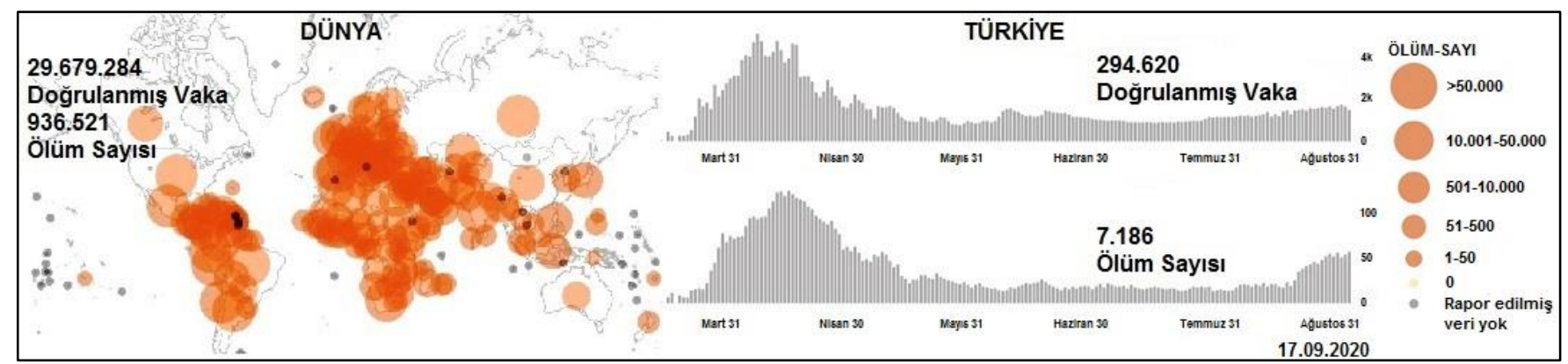

Şekil 1. COVID-19 pandemisi vaka ve ölüm sayıları (17.09.2020) (Anonymous, 2020b)

COVID-19 pandemisinin hızla yayılarak tüm dünyayı tehdit eder hale gelmesi, ülkelerin de farklı önlemler almasına sebep olmuştur. Artan hastalık ve ölüm vakaları birçok kısıtlamayı da beraberinde getirmiştir. Ülkemizde de bu süreçte uçuş yasakları, seyahat yasakları, sokağa çıkma yasakları, karantina, filyasyon, maske takma zorunluluğu gibi çeşitli önlemler ve tedbirler alınmıştır. Bu tedbirler ile vatandaşların pandemi süresi boyunca evde kalarak, serbest dolaşımın minimum seviyeye düşürülmesini amaçlayan izolasyon yaklaşımı, dünya genelinde ülkelerin benimsediği zorunlu bir yaklaşım haline gelmiştir (Düşünceli ve ark., 2020).

Ülkeler aldıkları önlem ve tedbirler ile COVID-19 pandemi döneminin muhtemel etkilerini azaltmaya çalışsalar da, birçok ülkenin başta sağlık, ekonomi ve eğitim olmak üzere tüm sistemlerini de etkilemiştir. Bu sistemlerden eğitim sistemi de bu süreçte önemli şekilde etkilenmiş ve değişime uğramıştır. Çoğu ülke ilk etapta COVID-19'un yayılma ve bulaşma ihtimalini en aza düşürmek ve gerekli tedbirleri almak için örgün eğitime ara vermiş veya eğitim dönemini sonlandırmıştır. Zaman içerisinde ise gerekli altyapı ve sistemler oluşturularak çoğu ülkede acil uzaktan öğretim sistemine geçilmiştir. Ülkemizde ise süreç bir süre yüz yüze eğitime ara verildikten sonra acil uzaktan öğretim sistemi ile devam ettirilmiştir.

COVİD-19 pandemi sürecinin, eğitim sistemi üzerine olan en büyük etkisi 01.04.2020 tarihinde gözlemlenmiştir. Tüm dünyada eğitim kurumlarının kapanmasından dolayı 1.596.842.024 öğrenci eğitimlerini sürdürememiş, 116.251.678 öğrenci ise kısmen açık olan yerlerde eğitimlerine devam edebilmişlerdir. Bu tarihte 193 ülkede eğitime ara verilmiş ve öğrencilerin \%91.2'si bu durumdan etkilenmiştir. 16.09.2020 tarihine gelindiğinde ise bu sayı, eğitim kurumlarının bir kısmının açılmasından dolayı 875.405.778'e düşmüş, kısmen açık olan yerlerde öğrenim görenlerin sayısı da 216.879.483'e çıkmıştır. Ancak 16.09.2020 tarihinde dahi bu durumdan öğrencilerin yaklaşık \%50'si etkilenmekte ve 53 ülkede ise hâlâ eğitim verilememektedir (Anonymous, 2020c) (Şekil 2).

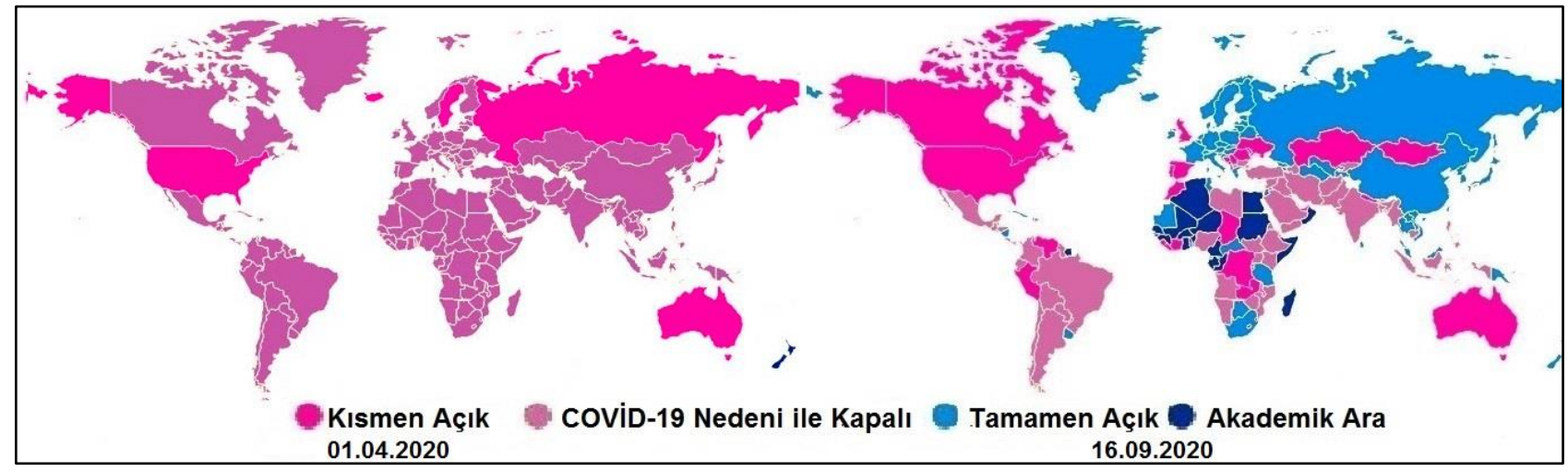

Şekil 2. COVID-19 pandemi sürecinde eğitim sistemi (01.04.2020,16.09.2020) (Anonymous, 2020c)

Ülkemizde ise 13 Mart 2020 tarihinde ilk ve orta öğretime, 16 Mart 2020 tarihinden itibaren de yükseköğretime ara verilmiştir (Anonim, 2020b; Dikmen ve Bahçeci, 2020). 23 Mart 2020 tarihinden itibaren ise 2019-2020 eğitim öğretim yılı bahar yarıyılının tamamen açık ve uzaktan öğretim sistemi ile sürdürülmesine karar verilmiştir (Anonim 2020c; Can, 2020). Bu süreçte 2019-2020 öğretim yılı verilerine göre Türkiye'de okul öncesi, ilköğretim ve ortaöğretimdeki öğrenci sayıs1 18.241.881 kişidir (Anonim, 2020d). Yükseköğretimdeki öğrenci sayısı ise 7.940.133 kişidir. Bunun 4.199.801 kişisi ise açık öğretim ve uzaktan eğitimde öğrenim görmektedir (Anonim, 2020e). Bu veriler dikkate alındığında, 2019-2020 eğitim öğretim yılı bahar yarıyılında, Türkiye'de COVİD-19 pandemi sürecinde etkilenen toplam öğrenci sayısı ise 21.982.213 kişidir (Şekil 3). 


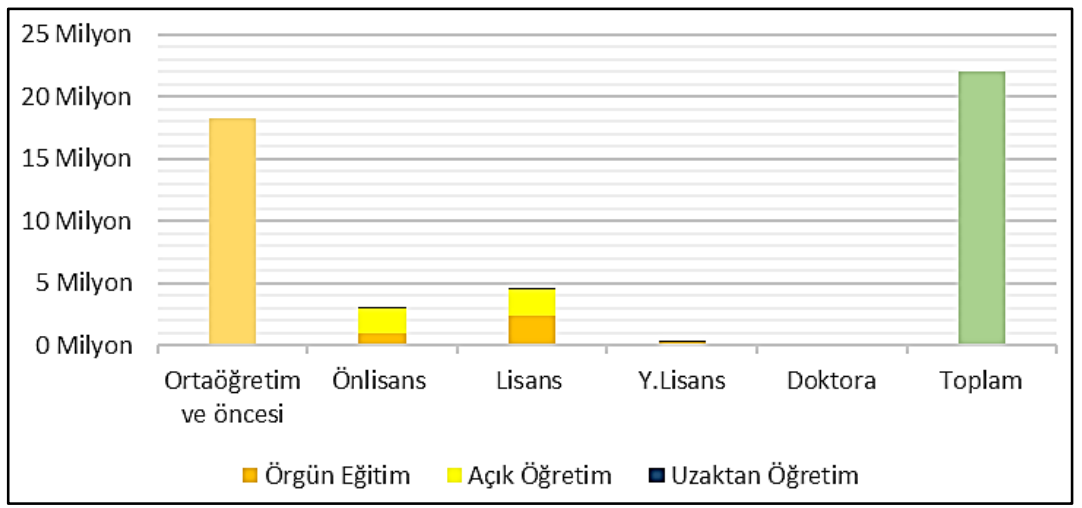

Şekil 3. COVID-19 pandemi sürecinden Türkiye'de etkilenen öğrenci sayıları (Anonim, 2020d-e)

$\mathrm{Bu}$ süreçten öğrencilerin en az şekilde etkilenmeleri ve eğitimlerine devam edebilmeleri için Türkiye'de hem Milli Eğitim Bakanlığı (MEB) hem de Yükseköğretim Kurumu (YÖK) bu dönemde çeşitli kararlar almışlardır. Milli Eğitim Bakanlığı tarafından, ilköğretim ve ortaöğretim düzeyinde açık ve uzaktan eğitim uygulamaları kapsamında 3 TV Kanalı ve Eğitim Bilişim Ağı (EBA) üzerinden eğitimlerin sürdürülmesine karar verilmiştir (Anonim, 2020g). Yükseköğretim Kurumu tarafindan ise özellikle Uzaktan Eğitim Birimi bulunan üniversitelerde, kendi alt yapılarını kullanarak ve eğitim-öğretim faaliyetlerini planlayarak eğitime devam etmeleri sağlanmıştır. Türkiye'de 123 Üniversitede Uzaktan Eğitim birimi bulunmaktadır. Uzaktan Eğitim Birimi bulunmayan üniversiteler için ise uzaktan eğitim alt yapısına veya açık öğretim kabiliyetine sahip üniversitelerden Yükseköğretim Kurulu koordinasyonu ile destek verilmesi kararlaştırılmıştır (Anonim, 2020f; Dikmen ve Bahçeci, 2020). $\mathrm{Bu}$ süreçte üniversitelerde öğretimlerini kendi imkân ve altyapılarına göre senkron (eşzamanlı) veya asenkron (eşzamanlı olmayan) şekilde sürdürmüşlerdir. Ayrıca Türkiye Radyo ve Televizyon Kurumu (TRT) bünyesinde bulundurduğu devlet adına yayın yapan televizyon kanallarını kullanarak ortak dersler verilmesi kararlaştırılmıştır (Anonim, 2020f; Dikmen ve Bahçeci, 2020).

Her ne kadar yüz yüze olmayan ve internet üzerinden yapılan eğitimi uzaktan eğitim olarak adlandırsak da aslında uzaktan eğitim ile acil uzaktan öğretim arasında gerek kullanılan araçlar gerekse sistemin işleyişi açısından önemli farklar bulunmaktadır. Pandemi döneminde yürütülen uzaktan eğitim, bir kriz anında yüz yüze eğitimin geçici olarak teknoloji ortamına aktarılmasıdır ve acil uzaktan ögretim veya acil durum uzaktan öğretim olarak isimlendirilmektedir. Yüz yüze ortamlar için hazırlanmış öğretim programları, ders materyalleri çevrim içi ortama taşınır, bu durum, acil durumlar için bir çözüm olarak ele alınır ve yaşam normale döndüğünde, sorun ortadan kalktığında tekrar yüz yüze eğitime geçilir. Bu koşullarda birincil amaç acil bir durum ya da kriz sırasında hızlı bir şekilde kurulabilecek ve güvenilir olarak kullanılabilecek eğitim ve öğretim desteklerine geçici erişim sağlamaktır (Akkoyunlu ve Bardakçı, 2020). Günümüzde uzaktan eğitim kavramı ülkemizde maalesef yanlış kullanılmakta hatta bu kavramı da zedelemektedir. Çünkü COVİD-19 pandemi sürecinde Türkiye'de yürütülen uzaktan eğitim değil, acil uzaktan öğretimdir.

Günümüzde yüz yüze eğitim, hibrit, acil uzaktan öğretim ve uzaktan eğitim sistemlerinin bu süreçte nasıl kullanılacağı halen tartışılmaktadır. Beklenmedik şekilde gelişen bu durum karşısında ülkeler de kendi altyapı, imkân ve pandemi olgu durumlarına göre farklı eğitim sistemlerini tercih etmektedirler. Fakat hangi sistem tercih edilirse edilsin, beklenilmeyen bu e-ISSN: 2148-2683 durumun, eğitim sistemi üzerine büyük etkilerinin olacağı ve öğretim sistemi araçlarını da değiştireceği açıktır.

$\mathrm{Bu}$ çalışmada, yüz yüze eğitime ara verilen dönemde, acil uzaktan öğretim sistemini kullanan öğrencilerin sistemi kullanım biçim ve tercihleri ile bu süreçte sistemde karşılaştıkları problemlerin saptanmasına çalışılmıştır. Çalışma sırasında elde edilen verilerle acil uzaktan öğretim sistemin sağladığı avantaj ve dezavantajlar analiz edilmiş ve yüz yüze eğitimle karşılaştırılarak eğitim ve öğretim sistemi üzerine olan etkileri açıklanmaya çalışılmıştır.

\section{Materyal ve Metot}

Bu araştırmada, COVİD-19 pandemi süreci nedeniyle yüz yüze eğitime ara verilmesi sonucunda, Burdur Mehmet Akif Ersoy Üniversitesi Peyzaj Mimarlığı Bölümü'nde eğitimlerine devam eden öğrencilerin acil uzaktan öğretim sistemi hakkındaki geri bildirimleri değerlendirilmiştir. Çalışma evreni olarak 20192020 bahar yarıyılında, Burdur Mehmet Akif Ersoy Peyzaj Mimarlığı bölümünde öğrenim gören tüm peyzaj mimarlığg lisans öğrencileri seçilmiştir. Araştırmada veri toplamak amacıyla 06.04.2020 ile 04.05.2020 tarihleri arasında bir çevrimiçi anket tasarlanarak, uygulamaya açılmıştır. Ankete 136 lisans öğrencisinden basit tesadüfi yöntem ile toplam 63 kişi katılmıştır $((1-\alpha)=0.95 ; \mathrm{E}=0.09)$.

Veri toplama aracı olarak kullanılan anket formunda toplam 18 adet soru sorulmuştur. İlk olarak demografik soruların ardından, öğrencilerin uzaktan eğitim sistemi ile daha önceden deneyimlerinin olup olmadığ öğretim sistemini hangi cihazlarla takip ettikleri belirlenmeye çalışılmıştır. Ardından yaşanılan süreçte öğrencilerin karşılaştıkları başlıca sorunların tespitine yönelik sorular yer almıştır. Sonraki bölümde ise öğrencilerin acil uzaktan öğretim sisteminin kullanımına yönelik görüşleri sorularak sistemin yeterliliği ve öğrenci davranışları sorgulanmıştır. Son bölümde ise acil uzaktan öğretim sisteminin nasıl uygulanması gerektiği konusunda öğrencilerin fikirleri alınarak, yüz yüze eğitimle ilgili karşılaştırma yapmaları istenmiştir.

Elde edilen anket sonuçlarının analiz ve değerlendirilmesi için SPSS (Statistical Package for Social Sciences) 26.0 istatistik paket programı kullanılmıştır. Araştırmada elde edilen anket verilerinin değerlendirilmesinde frekans, çapraz tablolama, paremetrik ve parametrik olmayan analizler uygulanmıştır. $\mathrm{Bu}$ kapsamda Mann Whitney U, Fisher exact ve T testi analizleri uygulanmıştır. Elde edilen sonuçlar doğrultusunda, acil uzaktan öğretim sisteminin etkileri üzerine değerlendirmeler yapılmıştır. 


\section{Araştırma Sonuçları ve Tartışma}

Çalışmaya katılan öğrencilerin 27'si (\%42.9) erkek, 36's1 (\%57.1) ise kadındır. Katılımciların 20'si (\%31.8) 1. sinıf öğrencisi iken, $18^{\prime}$ i (\%28.6) 2. sınıf, 12 'si (\% 19.0) 3. sınıf ve 13 'ü (\%20.6) ise 4. sınıf öğrencisidir (Şekil 4).

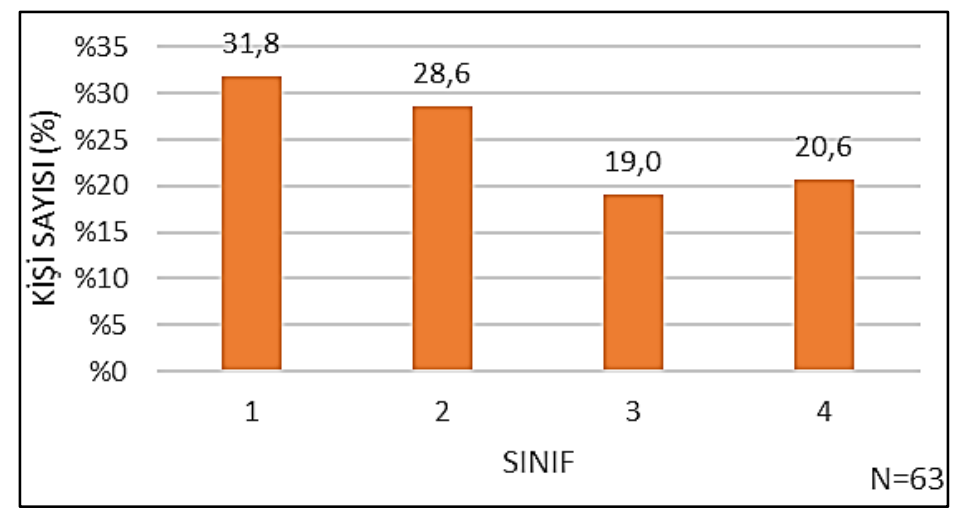

Şekil 4. Ankete katılan öğrenci sayılarının sinıflara göre dağgllımı

"Daha önce uzaktan eğitim ile bir deneyiminiz oldu mu?" sorusuna ise yine öğrencilerin çoğunluğunun 42'si (\%66.7) "Hayır" olmadı, geri kalan 21'i (\%33.3) ise "Evet" oldu şeklinde cevaplamışlardır.

Öğrencilere yöneltilen “Acil uzaktan öğretimi hangi cihazlarla takip ediyorsunuz?” sorusuna ise öğrencilerin büyük çoğunluğu, 50'si (\%79.4) "Bilgisayar" ile, geri kalan 13’ü (\%20.6) ise "Akıllı telefon" ile takip ettiklerini belirtmişlerdir. Bu soruda tablet seçeneğini ise öğrencilerden hiçbirinin tercih etmediği tespit edilmiştir. Sonuçlar Tablo 1'de çapraz tablo olarak verilmiştir.

Tablo 1. Öğrencilerin uzaktan eğitim deneyimleri ve cihaz tercihleri

Daha önce uzaktan eğitim ile ilgili bir deneyiminiz oldu mu?

Evet $21(\% 33.3)$

Hayır $42(\% 66.7)$

$(\mathrm{N}=63)$

Acil uzaktan öğretimi hangi cihazlardan takip ediyorsunuz?

Acil uzaktan öğretimi hangi cihazlardan takip ediyorsunuz?

\begin{tabular}{cccccc}
\hline Bilgisayar & Ak1ll telefon & Tablet & Bilgisayar & Ak1ll telefon & Tablet \\
\hline 15 & 6 & 0 & 35 & 7 & 0 \\
\hline
\end{tabular}

Sonuçlar incelendiğinde, öğrenci deneyimi ile cihaz seçimi arasında anlamlı bir fark olmadığı tespit edilmiştir $(\mathrm{p}=.218)$. Cevaplar ele alındığında öğrencilerin çoğunluğunun uzaktan eğitim sistemini daha önce deneyimlemedikleri görülmektedir. Ayrıca daha önce uzaktan eğitim gören öğrencilerin dâhi cihazla ilgili soruya tablet cevabını vermedikleri görülmektedir. Bu da tablet kullanımının ülkemizde yaygınlaşmasına rağmen, kullanım sinırlılıkları ve fiyatı nedeni ile öğrencilerin ilk tercih olarak bilgisayar seçeneğini seçtiklerini düşündürmektedir.
Öğrencilere yöneltilen “Acil uzaktan öğretim süreci ile ilgili karşılaştığınız en büyük problem nedir?” şeklindeki çoklu cevaplı soruya ise öğrenciler, birinci sırada \%42.9 ile "İnternet bağlantı sorunu", ikinci surada \%25.5 ile "Motivasyon zorluğu (Bireysellik)", üçüncü sırada ise \%12.2 ile "İnternet kota sorunu" ve "Bilgisayardan takip etme zorluğu" olarak cevap vermişlerdir (Şekil 5).

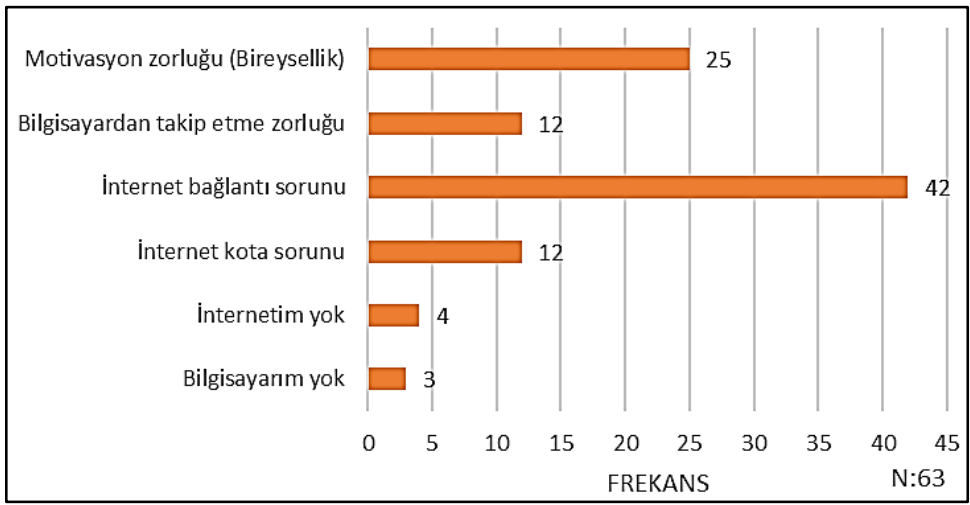

Şekil 5. Öğrencilerin acil uzaktan öğretim sürecinde karşılaştıkları problemler (Çoklu cevap) 
Sonuçlar incelendiğinde, acil uzaktan öğretim sürecinde karşılaşılan problemlerin ilk sırasında internet bağlantı sorunu olduğu görülmektedir. Bu nokta ülkemizde internet altyapının güçlenmesine karşın hâlâ eksik olduğu ortaya çıkmaktadır. Oysa internete dayalı olarak verilen acil uzaktan öğretim sistemi kesintisiz ve hızlı bir internet altyapısına ihtiyaç duymaktadır. Yaşanan süreç içerisinde özellikle sınav dönemlerinde ve çok öğrencinin katıldı ̆̆ 1 derslerde sisteme erişimin durma noktasına geldiği görülmektedir. Bu noktada da gerek internet altyapısının gerekse de eğitim kurumlarımızdaki teknolojik altyapının güçlendirilmesi gerekmektedir.
Sonuçlarda ikinci sırada ise öğrencilerin karşılaştı̆̆ 1 bir diğer önemli sorunun motivasyon zorluğu (Bireysellik) olduğu görülmektedir. Öğrencilerin karşılaştığ 1 motivasyon zorluğu (Bireysellik) konusunda çapraz tablo sorgulaması yapıldığında ise kadın öğrencilerin motivasyon konusunda erkek öğrencilere oranla daha fazla zorlandıkları ortaya çıkmıştır $(\mathrm{t}(61)=2.604 ; \mathrm{p}$ $=.012$ ) (Şekil 6). Bu noktada öğrencinin tek başına kalması, sınıf ortamından ve arkadaşlarından uzaklaşması motivasyonunu olumsuz yönde etkilemektedir. Bunun için ders anlatımlarında yüz yüze eğitimden farklı alternatif yöntemlerle dersler daha ilgi çekici hale getirilmeli ve öğrencilerin derse katılımları arttırılmalıdır.

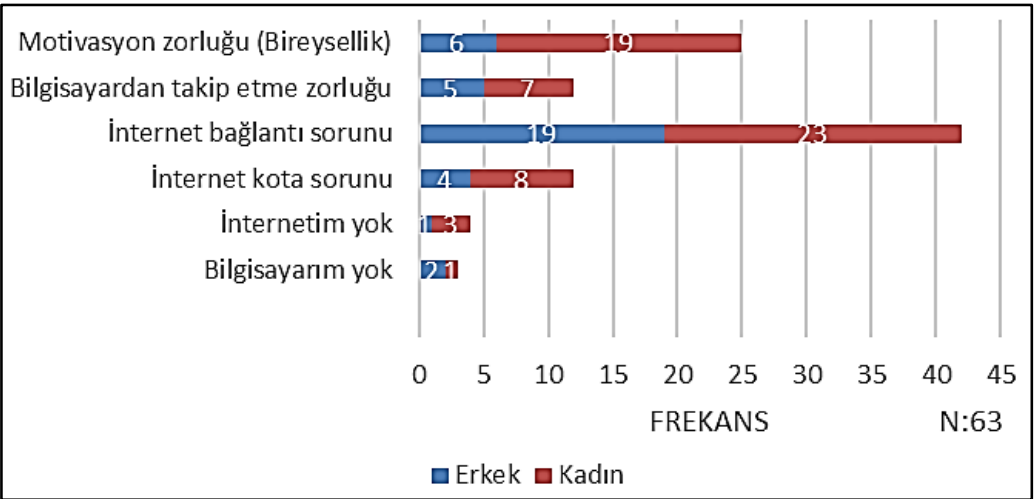

Şekil 6. Öğrencilerin acil uzaktan öğretim sürecinde karşılaştıkları problemlerde kadın-erkek dă̆llımı

Sonuçlarda üçüncü sırada görülen internet kota sorunu ve bilgisayardan takip etme zorluğu da öğrencilerin karşılaştı̆̆ bir başka önemli sorundur. Canlı ders kayıtlarını izlemek isteyen öğrenciler video kayıtlarını takip ettiklerinden video kullanımı da aynı zamanda daha fazla internet kullanımı gerektirmektedir. $\mathrm{Bu}$ yüzden de öğrenciler internette kota sıkıntısı yaşamaktadırlar. Bu sıkıntının giderilmesi için öğrencilere mutlaka kota desteği sağlanmalıdır. İlk bölümde öğrencilerin \% 79.4'ünün bilgisayar ile kalan \%20.6'sının ise cep telefonu ile acil uzaktan ögretimi takip ettikleri tespit edilmişti. Evlerde acil uzaktan öğretimi takip edebilecek teknolojik araç olmaması veya sınırlı sayıda olması, öğrencileri olumsuz yönde etkilemektedir. $\mathrm{Bu}$ yüzden öğrencilerin dersleri rahat takip edebilmeleri için evlerde her öğrenciye özel teknolojik araç imkânı sunulmalıdır.
Öğrencilerin acil uzaktan öğretim sisteminin kullanımına yönelik görüşleri ise 10 soru ve 5'li likert ölçeği ile değerlendirilmiştir. Anket verileri incelendiğinde, öğrencilerin \%82.5'i ders notlarına, \%60.3'ünün ise ders kayıtlarına hızla ulaştıkları görülmektedir. Öğrencilerin \%63.4'ü duyuruları düzenli olarak takip etmekte ve $\% 63.5$ 'i ise katılamadığ 1 dersleri kayıtlardan takip etmektedirler. Sürekli tekrar sağlayan öğrenciler $\% 49.2$ iken, vakit tasarrufu sağlayanların sayısı ise \%54.0'dür. Sistemde teknik problemlerle karşılaşan öğrenci sayısı \%58.7'dir. Öğrencilerin \%61.9'u sistemi karmaşık bulmadığını ifade ederken, \%52.4'ü ise acil uzaktan öğretim sistemi ile daha hızlı öğrenmediğini ifade etmiştir. Canlı derslerin düzenli takibi konusunda ise öğrenciler tamamen kararsız kalmışlardır (Şekil 7).

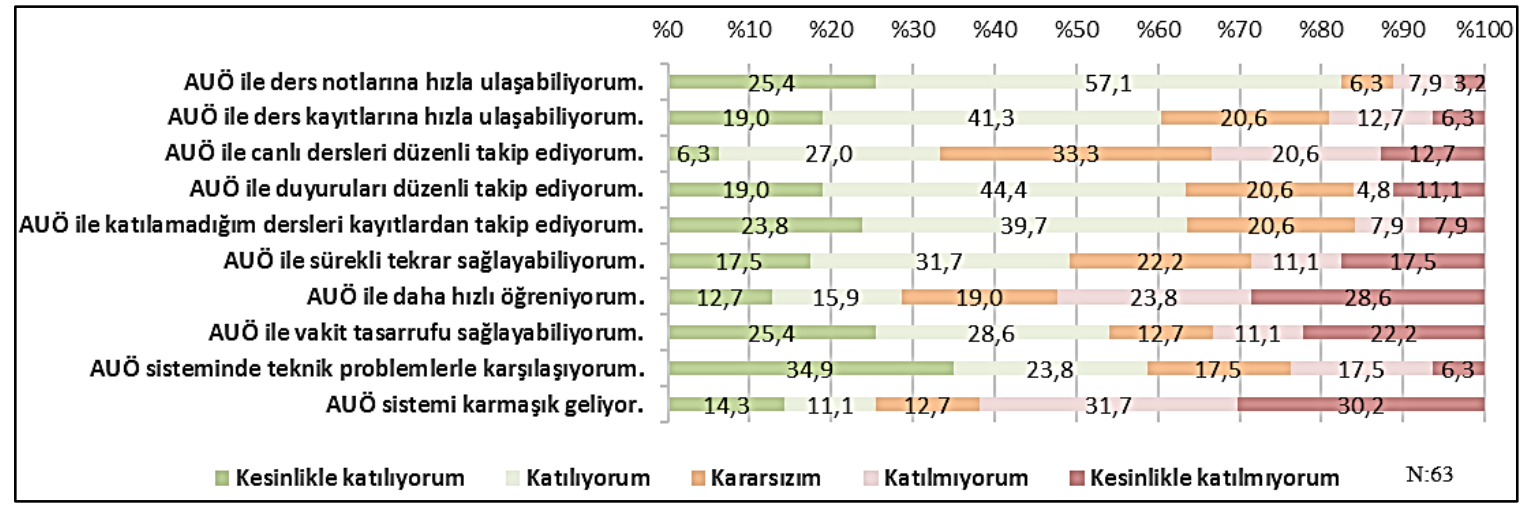

Şekil 7. Öğrencilerin acil uzaktan öğretim sisteminin kullanımına yönelik görüşleri

Sonuçlar incelendiğinde, acil uzaktan öğretim sisteminde öğrencilerin ders notlarına ve kayıtlarına ulaşmada herhangi bir sıkıntı yaşamadıkları görülmektedir. Ayrıca gerek duyuruları gerekse kaçırdıkları ama kayıt altına alınmış dersleri öğrencilerin takip ettiği de tespit edilmiştir. Sistem ders notlarında, canlı derslerde ve kayıt altına alınan derslerde, öğrencilerin ihtiyaçlarına cevap verebilecek düzeydedir. Kayıt altına alınan dersler sayesinde bu noktada öğrencilerin dersleri tekrar ettikleri de sonuçlarda görülmektedir. Sistemin öğrencilerin öğrenme hızına etkisi ise görülmemiştir. Bunda derslerde uygulama yapılamaması ve yüz yüze eğitim avantajlarının kullanılamamasının etkisi büyüktür.

Sonuçlar incelendiğinde, canlı derslerin düzenli takip edilmesi noktasındaki öğrencilerin kararsızlıkları bir kez daha 
motivasyon konusunun irdelenmesi gerektiğini ortaya çıkarmaktadır. Canlı derse gerek yok, nasıl olsa tekrar kayıttan izleriz; yaklaşımı öğrencinin soru sorma ve çabuk kavrama gibi imkânları yitirmesine ve çalışma disiplininden uzaklaşmasına neden olmaktadır. Öğrencilerin de belirttiği gibi mekan bağımsız çalışma, öğrencilere vakit tasarrufu sağlamıştır. Ancak kazanılan bu zamanın boşa harcanmaması gerekmektedir.

Sistem kullanım açısından incelendiğinde ise günümüz teknolojisine daha çabuk adapte olan öğrenciler sistemi karmaşık bulmamakta ve kullanım esnasında zorlanmamaktadırlar. Fakat sistemle ilgili teknik problemler burada da etkisini göstermektedir. $\mathrm{Bu}$ noktada eğitim kurumlarının kullandığ 1 yazılım, teknolojik altyapı ve internet altyapısı bir kez daha ön plana çıkmaktadır.
Öğrencilerin acil uzaktan öğretim sisteminin kullanımına ilişkin cevaplarının, cinsiyet açısından farklılık gösterip göstermediği ise $\mathrm{t}$ testi ile incelenmiştir. Buna göre, farklılık "Canlı derslerin düzenli takibi" noktasında ortaya çıkmıştır. Bu soruda kadınların erkeklere kıyasla canlı dersleri daha düzenli takip ettikleri sonucuna ulaşılmıştır $(\mathrm{t}(61)=2.174 ; \mathrm{p}=.034)$.

Öğrencilere yöneltilen "Acil uzaktan öğretim, yüz yüze eğitimle eşdeğer midir?" sorusuna ise 19 (\%30.2) öğrenci "Evet", 44 (\%69.8) öğrenci ise "Hayır" şeklinde cevaplandırmıştır. "Bölümünüzdeki dersler için acil uzaktan öğretim, yüz yüze eğitim kadar verimli midir?" sorusuna ise öğrencilerin 26's1 $(\% 41.3)$ "Evet", 37'si (\%58.7) ise "Hayır" şeklinde cevaplandırmıştır (Şekil 8).

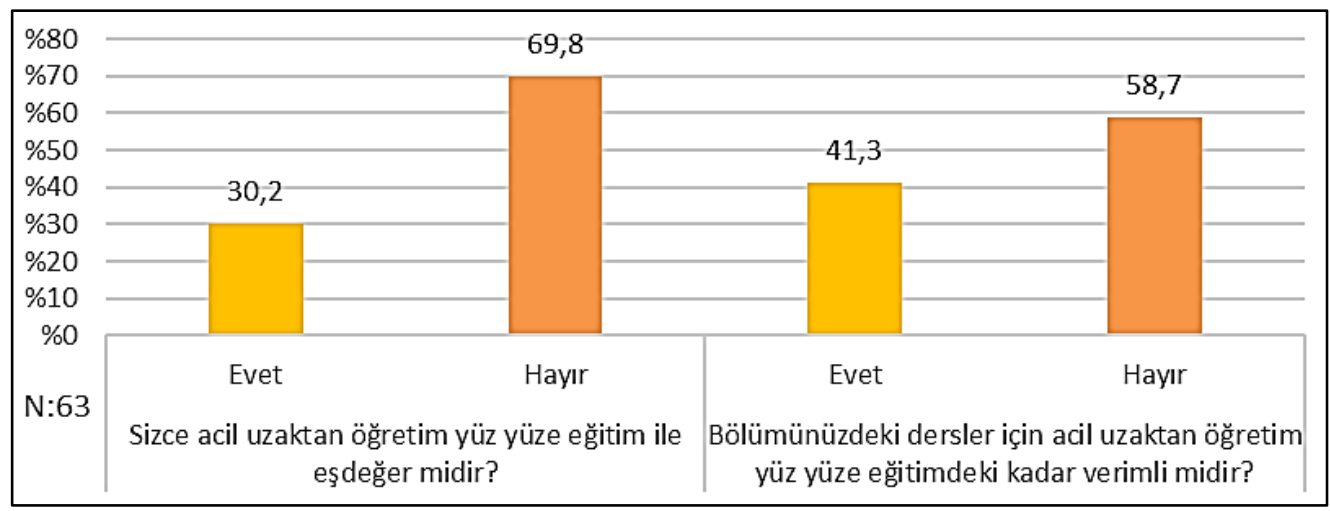

Şekil 8. Öğrencilerin acil uzaktan öğretim ve yüz yüze eğitim hakkındaki görüşleri

Sonuçlar incelendiğinde, öğrencilerin acil uzaktan öğretimi, yüz yüze eğitim kadar verimli bulmadıkları ve yüz yüze eğitimle eşdeğer tutulamayacağı konusunda hemfikir oldukları görülmektedir. $\mathrm{Bu}$ sonucun çıkmasında peyzaj mimarlığ bölümündeki uygulamalı derslerin payı büyüktür. Elde edilen cevaplar incelendiğinde sınıf düzeyi açısından anlamlı bir farklılık gösterdiği tespit edilmiştir $(U=289.0 ; p=.045 ; \mathrm{r}=0.25)$. Sonuçlar sınıf düzeyinde incelendiğinde, dördüncü sınıf öğrencilerinin, diğer sınıflardan farklı olarak acil uzaktan öğretimi, yüz yüze eğitimle eşdeğer gördükleri sonucu ortaya çıkmıştır (Şekil 9). Bölüm dersleri açısından da cevaplar incelendiğinde, sınıf düzeyi açısından gene anlamlı bir farklılık gösterdiği tespit edilmiştir $(\mathrm{U}=322.5 ; \mathrm{p}=.022 ; \mathrm{r}=0.29)$. Bölüm derslerinde dördüncü sınıf öğrencilerinin, acil uzaktan öğretimi yüz yüze eğitimden daha verimli buldukları, üçüncü sınıf öğrencilerinin ise bu konuda kararsız kaldıkları görülmektedir (Şekil 9). Dördüncü sınıfta netleşen bu farklılıkta, öğrencilerin ders yüklerinin azalması ve çizim, tasarım gibi uygulamalı derslerin azalarak dönem bazında teke düşmesi gibi nedenlerin etken olduğu düşünülmektedir.

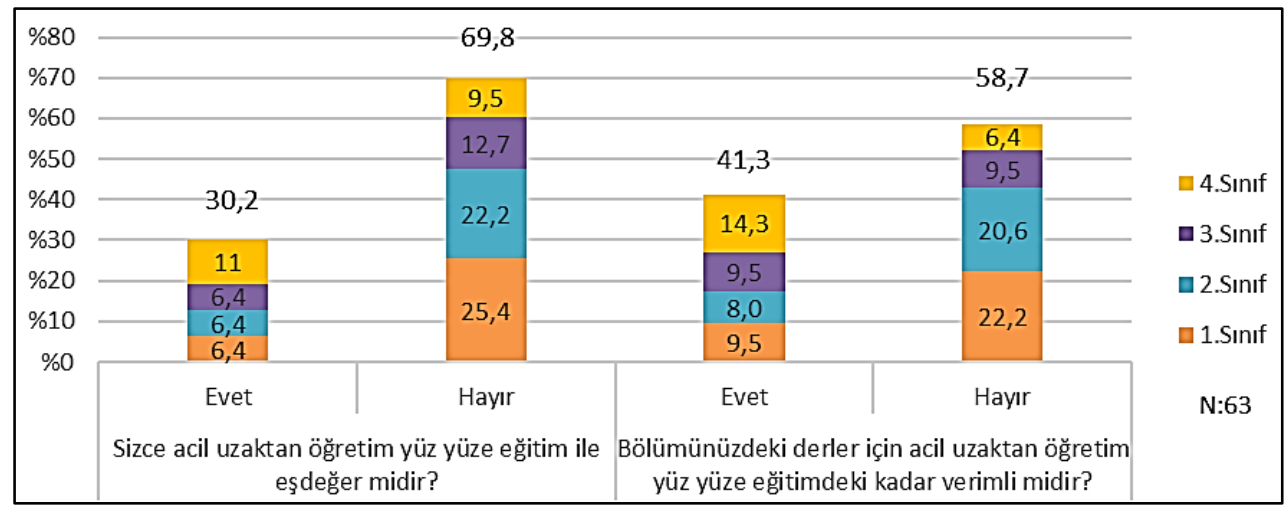

Şekil 9. Öğrencilerin sınıf düzeyinde acil uzaktan öğretim ve yüz yüze ĕgitim hakkındaki görüşleri

"Bölümünüzdeki derslerin uygulanma şekli için tercihiniz hangisidir?" sorusuna ise öğrenciler, birinci sırada 28 (\%44.4) öğrenci ile "Uygulaması olmayan dersleri acil uzaktan öğretim ile almak isterim", 2. sırada 15 (\%23.8) öğrenci ile "Tüm dersleri acil uzaktan öğretim ile almak isterim”, 3. Sırada 14 (\%22.2) öğrenci ile "Tüm dersleri yüz yüze almak isterim", 4. Sirada ise $6(\% 9.6)$ öğrenci ile "Fikrim yok" şeklinde cevaplamışlardır (Şekil 10).
Sonuçlar incelendiğinde, peyzaj mimarlığı bölümünde okuyan öğrencilerin sadece \%23.8'inin tamamen acil uzaktan öğretimi tercih ettiği görülmektir. Süreç incelendiğinde de teorik derslerin acil uzaktan öğretim ile sürdürülmesinde herhangi bir sıkıntı gözlemlenmemiştir. Fakat uygulamalı derslerin işleyişinde bilgisayar destekli tasarım dersleri hariç ciddi sıkıntılar yaşanmaktadır. Özellikle çizim, tasarım, laboratuvar, arazi, teknik gezi ve maket çalışmaları içeren, öğrencilerin deneyimleyerek, tekrarlayarak ve gözlemleyerek öğrenebilecekleri, eğitimcilerin 
de öğrenim sürecinde daha etkin rol aldıkları uygulamalı derslerde süreç maalesef sağlıklı bir şekilde yürütülememektedir.
Aynı şekilde anket sonuçları da incelendiğinde, öğrencilerin de ilk sırada \%44.4 ile bu görüşe katıldıkları görülmüştür.

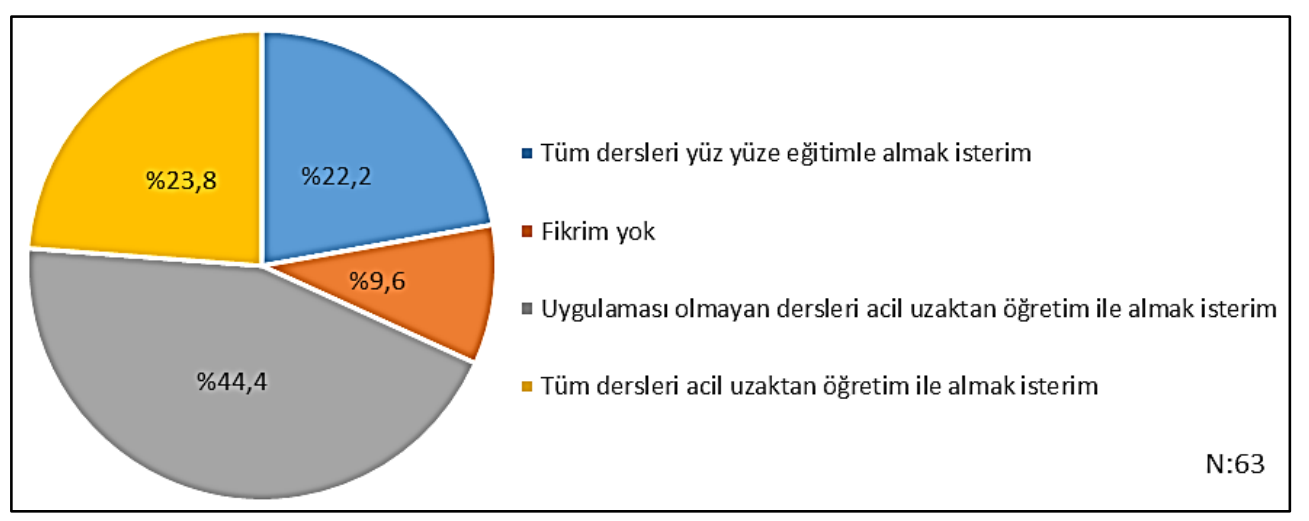

Şekil 10. Peyzaj mimarlı̆̆ bölümünde okutulan derslerin uygulanma şekline ilişkin öğrenci görüşleri

Elde edilen cevaplar, sınıf düzeyinde incelendiğinde ise verilen cevapların sınıf düzeyinde anlamlı bir farklılık göstermediği tespit edilmiştir $(\mathrm{p}=.054)$. Buna karşın sonuçlar inceleğinde fikrim yok seçeneğini seçen öğrencilerin birinci ve ikinci sınıfta oldukları ve tüm dersleri acil uzaktan öğretim ile almak isteyen öğrenci sayısının ise gene dördüncü sınıfta artış gösterdiği tespit edilmiştir (Şekil 11).

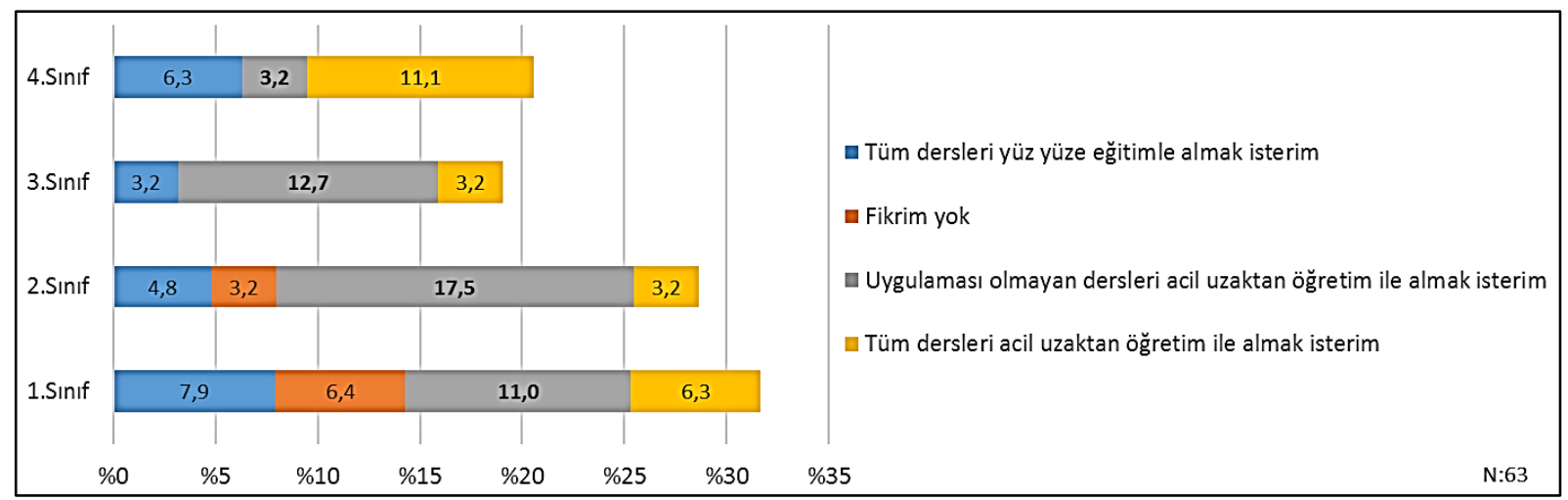

Şekil 11. Peyzaj mimarlı̆̆ bölümünde okutulan derslerin uygulanma şekline ilişkin sınıf düzeyinde ögrenci görüşleri

Üniversiteye ve bölüme yeni başlayan öğrencilerin ders içerikleri ve derslerin işleniş biçimi hakkında fazla bilgiye sahip olmadıklarından dolayı fikrim yok seçeneğinin birinci ve ikinci sınıflar tarafından tercih edildiği düşünülmüştür. Tüm dersleri acil uzaktan öğretim ile almak isteyen öğrenci sayının dördüncü sınıfta artmasının nedeni olarak ise ders yüklerinin azalması ve çizim, tasarım gibi uygulamalı derslerin dönem bazında teke düşmesinin sebep olduğu düşünülmüştür. Bu sonucun çıkmasında öğrencilerin gerek son sınıfa kadar almış oldukları eğitimle gerekse kendi çabaları ile dijital tasarım becerilerini geliştirerek, bu araçları diğer sınıf öğrencilerine oranla daha etkin kullanmalarının ve bu sayede çizim, tasarım gibi derslerin üstesinden daha kolay gelebilmelerinin de etken olduğu sanılmaktadır. Ayrıca, dördüncü sınıf öğrencilerinde yaşanan mezuniyet kaygısı nedeni ile acil uzaktan öğretimin kendilerine daha kolay ders geçme imkânı tanıyacağı yönündeki algılarınında sonucu etkilediği düşünülmektedir.

\section{Sonuç}

Yaşanan süreç ve araştırma sonuçları analiz edildiğinde, acil uzaktan öğretimin kısa sürede birçok ihtiyacı karşıladığı, eğitim ve öğretim sürecinin devam ettirilmesine fayda sağladığ görülmektedir. Fakat bu faydaların yanında acil uzaktan öğretimin yüz yüze eğitim kadar başarılı olamadığı ve birçok sorunu da beraberinde getirdiği yadsınamaz bir gerçektir.
Araştırma sonuçlarına göre sistemde karşılaşılan sorunlar ele alındığında, Türkiye'de acil uzaktan öğretimde karşılaşılan en büyük sorun altyapı eksiklikleridir. Bu eksiklikleri gidermek için gerek internet altyapısı, gerekse üniversite teknoloji altyapıları bu talebi karşılayacak şekilde mutlaka geliştirilmelidir. Çünkü sistemin vazgeçilmezi kesintisiz ve hızlı internettir. Bu noktada karşılaşılan bir başka önemli sorun da sistem için kullanılan yazılım tercihidir. Eğitim kurumlarının doğru yazılımları tercih etmeleri bu noktada büyük önem taşımaktadır. Eğitim kurumlarının, konferans sistemi yazılımları entegre edilmiş sistemlerden ziyade kendi web tabanlı uygulamalarını geliştirmeleri, olası birçok karmaşa ve güvenlik sorunlarının önüne geçecektir. Acil uzaktan öğretim sistemi kullanılırken yaşanan sorunların daha hızlı çözümü içinse mutlaka daha fazla bilgilendirme yapılmalı ve rehberlik hizmetleri sunulmalıdır. Ayrıca kütüphane gibi kampüs içi olanakları da sisteme dâhil ederek öğrencilerin sistemden daha fazla yararlanması sağlanmalıdır.

Süreç incelendiğinde acil ve beklenmeyen bu durum karşısında eğitmenlerin de birçok konuda eksik kaldığı ve yeteri kadar hazırlanamadığı görülmektedir. Eğitimin aksamaması için eğitmenler de ders anlatımlarını ve ders notlarını yeni sisteme göre alelacele yeniden düzenlemek zorunda kalmışlardır. Acil uzaktan öğretim sistemine uygun eğitim materyallerinin hazırlanmasında, eğitmenlerin bilgi ve becerilerinin de sınırlı olduğu düşünülürse eğitmenlerinde bu konuda mutlaka desteklenmesi gerekmektedir. Çoğu eğitmen bu sistemin 
kullanımıyla ilgili herhangi bir eğitim almadığı gibi kendilerini de aslında daha önce deneyimlemedikleri bir sisteme adapte etmek zorunda kalmışlardır. Bu da oluşabilecek sorunların önüne geçme noktasında eğitmenleri ancak yaşa ve gör seçeneği ile hareket etmek zorunda bırakmıştır. Eğitmenler açısından bir başka önemli nokta da verilen ödevlerin ve yapılan sınavların şeffaflığı ve güvenirliliğidir. Sınav ve ödev uygulamaları ile bunların değerlendirilmesi noktasında mutlaka alternatif çözümler getirilmelidir.

Acil uzaktan öğretim sistemi öğrenciler açısından incelendiğinde ise öncelikle öğrenciler arasında teknolojik eşitlik sağlanmalıdır. Çünkü günümüzde hâlâ dersleri takip edecek teknolojik araçlara sahip olmayan öğrenciler bulunmaktadır. Öğrencilerin teknolojik gelişmeleri daha yakından takip ettikleri ve sisteme çabuk adapte oldukları görülmektedir. Öğrencilerin canlı derslerden ziyade video kayıtlarını takip ettikleri görülmüştür. Fakat video kayıtlarının kullanımı fazla internet kullanımı gerektirdiği için, kota desteği öğrencilere mutlaka sağlanmalıdır. Acil uzaktan eğitim her ne kadar zaman ve mekandan bağımsız çalışma esnekliği sağlasa da öğrencilerin aktif katılımlarının düşük olduğu görülmektedir. Katılımların arttırılarak, disiplin eksikliği giderilmeli ve öğrenci motivasyonunun düşmesine izin verilmemelidir. Canlı ders kayıtlarının tekrar izlenebilmesi öğrencinin tekrar edebilmesine katkı sağlarken derslerin düzenli takibi noktasında öğrencileri kararsızlığa sürüklemiştir. Ödev ve sınavlara odaklanmada öğrencilerin sorun yaşamaması için öğrencilerin derse olan ilgileri arttırılmalıdır.

Süreç peyzaj mimarlığı bölümleri açısından incelendiğinde ise acil uzaktan öğretimde, özellikle uygulamalı derslerde, hem öğrencilerin hem de eğitmenlerin zorlandığı görülmektir. Çok bileşenli uygulamalı derslerde, derslerin acil uzaktan öğretim sistemiyle işlenmesi nedeniyle öğrenciler kendilerini keşfedememektedirler. Eğitmenler ise öğrencilerin yatkın olduğu alanları ortaya çıkartmakta ve öğrencileri yönlendirme konusunda zorlanmaktadırlar. Uygulamalı derslerde çizim, tasarım, laboratuvar, arazi, teknik gezi ve maket çalışmaları yeteri kadar ya da hiç yapılamadığı için öğrenciler deneyim kazanamamakta, eğitmenler de öğrencilerin teknik becerilerini yeteri kadar ölçememekte ve katkı sağlayamamaktadır. Özellikle tasarım ve çizim içeren derslerin paylaşım ortamında yürütülememesi ve stüdyo kültüründen kopuk işlenmesi sebebiyle öğrencilerde motivasyon düşüklüğü ve eleştirel düşünceden uzaklaştıkları görülmektedir. Bu noktada öğrencilerin aktif deneyimleme ve gözlem ile edindikleri bilgileri işlemede yüz yüze yapılan uygulamalı derslerde daha kolay gerçekleştirebildikleri görülmektedir. $\mathrm{Bu}$ yüzden acil uzaktan öğretimin, peyzaj mimarlığı bölümlerindeki uygulamalı derslerde, bilgisayar destekli tasarım dersleri hariç, bu şartlarla kullanılmasının uygun olmayacağ1 görüşüne varılmıştır.

\section{Kaynakça}

Anonim, (2020a). T.C. Sağlık Bakanlığı, COVİD-19 Haftalık Durum Raporu 06.07.2020-12.07.2020 Türkiye, 13.07.2020.

Anonim, (2020b). T.C. Sağlık Bakanlığı, Haberler, https://www.saglik.gov.tr-/Genel/MansetHaberListesi.aspx, (Erişim tarihi: 10.09. 2020).

Anonim, (2020c). YÖK, Basın açıklaması, https://www.yok.gov. tr/Sayfalar/Haberler/2020/YKS\%20Ertelenmesi\%20Basin\% 20Açıklaması.aspx, (Erişim tarihi: 05.09.2020).
Anonim, (2020d). T.C. Milli Eğitim Bakanlığı Strateji Geliştirme Başkanlığ1, Milli Eğitim İstatistikleri, Örgün Eğitim, 2019/'20.

Anonim, (2020e). YÖK, Yüksek Öğretim Bilgi Yönetim Sistemi. https://istatistik.yok.gov.tr/, (Erişim tarihi: 15.09.2020).

Anonim, (2020f). YÖK, Üniversitelerde uygulanacak uzaktan eğitime ilişkin açıklama. https://www.yok.gov.tr/Sayfalar/ Haberler/2020/universitelerde-uygulanacak-uzaktaneğitime ilişkin-acikla ma.aspx, (Erişim tarihi: 08.09.2020).

Anonim, (2020g). T.C Milli Eğitim Bakanlığı, Haberler. https://www.meb.gov.tr/bakan-selcuk-koronaviruse-karsiegitim-alaninda-alinan-tedbirleri-acikladi/haber/20497/tr, (Erişim tarihi: 13.09.2020).

Anonymous, (2020a). Aljazeera. Timeline: How the new coronavirus spread. https://www.aljazeera.com/news/2020/ 01/timeline-china-coronavirus-spread-200126061554884. html, (Date of access: 20 September 2020).

Anonymous, (2020b). WHO (World Health Organization), WHO Coronavirus Disease (COVID-19) Dashboard. https:// covid19.who.int/, (Date of access: 17 September 2020).

Anonymous, (2020c). UNESCO (United Nations Educational, Scientific and Cultural Organization), COVID-19 Impact on

Akkoyunlu, B., Bardakçı, S. (2020). Yükseköğretim Kalite Kurulu, Pandemi Döneminde Uzaktan Eğitim. https://portal. yokak.gov.tr/makale/pandemi-doneminde-uzaktan-egitim/, (Erişim tarihi: 11.09.2020).

Can, E. (2020). Coronavirüs (COVID-19) pandemisi ve pedagojik yansımaları: Türkiye'de açık ve uzaktan eğitim uygulamaları. Açık öğretim Uygulamaları ve Araştırmaları Dergisi, 6 (2), 11-53.

Dikmen, S., Bahçeci, F. (2020). COVID-19 Pandemisi Sürecinde Yükseköğretim Kurumlarının Uzaktan Eğitime Yönelik Stratejileri: Frrat Üniversitesi Örneği. Turkish Journal of Educational Studies, 7 (2), 78-98. DOI: 10.33907/turkjes. 721685.

Düşünceli, F., Arı, Ö., Evren, M., Kavak, O. (2020). COVİD-19 Sürecinde Mardin Artuklu Üniversitesi, Uzaktan Eğitim Sistemi, Eğitim-Öğretim ile Araştırma Faaliyetlerinin Değerlendirilmesi. Haziran 2020.

Taş, M.B.H., Yağanoğlu, M. (2020). Ağır Akut Solunum Yolu Yetersizliği Sendromu Koronavirüsü 2 (SARSCoV-2) Dünya Çapındaki Analizi ve Gelecekteki Durumu. Avrupa Bilim ve Teknoloji Dergisi, (20), 248-253. DOI: 10.31590/ejosat. 764638. 